\title{
Safeguarding Biodiversity and Ecosystem Services in the Little Karoo, South Africa
}

\author{
BENIS N. EGOH, ${ }^{*} \dagger \neq \ddagger$ BELINDA REYERS, $†$ JOSIE CARWARDINE, $\ddagger$ MICHAEL BODE,$\S$ \\ PATRICK J. O'FARRELL,$\dagger$ KERRIE A. WILSON,$\neq$ HUGH P. POSSINGHAM,$\neq$ MATHIEU ROUGET, ${ }^{* *}$ \\ WILLEM DE LANGE, $†$ DAVID M. RICHARDSON, ${ }^{*}$ AND RICHARD M. COWLING†† \\ ${ }^{*}$ Centre for Invasion Biology, Department of Botany and Zoology, Stellenbosch University, Private Bag X1, Matieland 7602, South \\ Africa \\ †Natural Resources and the Environment, Council for Scientific and Industrial Research, P. O. Box 320, Stellenbosch, 7599, South \\ Africa \\ ‡The University of Queensland, The Applied Environmental Decision Analysis Centre, The Ecology Centre, Brisbane, Queensland \\ 4072, Australia \\ $\S$ Applied Environmental Decision Analysis Group, School of Botany, The University of Melbourne, Parkville, 3010, Australia \\ ** South African National Biodiversity Institute, Private Bag x101, Pretoria 0001, South Africa \\ t†Department of Botany, Nelson Mandela Metropolitan University, P. O. Box 77000, Port Elizabeth 6031, South Africa
}

\begin{abstract}
Global declines in biodiversity and the widespread degradation of ecosystem services have led to urgent calls to safeguard both. Responses to this urgency include calls to integrate the needs of ecosystem services and biodiversity into the design of conservation interventions. The benefits of such integration are purported to include improvements in the justification and resources available for these interventions. Nevertheless, additional costs and potential trade-offs remain poorly understood in the design of interventions that seek to conserve biodiversity and ecosystem services. We sought to investigate the synergies and trade-offs in safeguarding ecosystem services and biodiversity in South Africa's Little Karoo. We used data on three ecosystem services-carbon storage, water recharge, and fodder provision-and data on biodiversity to examine several conservation planning scenarios. First, we investigated the amount of each ecosystem service captured incidentally by a conservation plan to meet targets for biodiversity only while minimizing opportunity costs. We then examined the costs of adding targets for ecosystem services into this conservation plan. Finally, we explored trade-offs between biodiversity and ecosystem service targets at a fixed cost. At least 30\% of each ecosystem service was captured incidentally when all of biodiversity targets were met. By including data on ecosystem services, we increased the amount of services captured by at least $20 \%$ for all three services without additional costs. When biodiversity targets were reduced by $8 \%$, an extra $40 \%$ of fodder provision and water recharge were obtained and 58\% of carbon could be captured for the same cost. The opportunity cost (in terms of forgone production) of safeguarding 100\% of the biodiversity targets was about US\$50O million. Our results showed that with a small decrease in biodiversity target achievement, substantial gains for the conservation of ecosystem services can be achieved within our biodiversity priority areas for no extra cost.
\end{abstract}

Keywords: biodiversity assessments, carbon storage, conservation planning, fodder provision opportunity cost, payments for ecosystem services, water recharge

Salvaguardando la Biodiversidad y los Servicios del Ecosistema en Pequeño Karoo, Sudáfrica

Resumen: Las declinaciones globales de biodiversidad y la degradación generalizada de los servicios del ecosistema han conducido a llamados urgentes para salvaguardarlos. Las respuestas a esta urgencia 
incluyen llamados para integrar las necesidades de los servicios del ecosistema y la biodiversidad en el diseño de intervenciones de conservación. Los beneficios de tal integración pretenden incluir mejoras en la justificación y recursos disponibles para estas intervenciones. Sin embargo, los costos adicionales y desventajas potenciales son poco conocidas en el diseño de intervenciones que buscan conservar la biodiversidad y los servicios del ecosistema. Tratamos de investigar las sinergias y desventajas de salvaguardar los servicios del ecosistema y la biodiversidad en el Pequeño Karoo en Sudáfrica. Utilizamos datos de tres servicios del ecosistema - almacenamiento de carbono, recarga de agua y provisión de forraje - y datos de la biodiversidad para examinar varios escenarios de planificación de la conservación. Primero, investigamos la cantidad de servicio ambiental capturado incidentalmente por un plan de conservación para alcanzar objetivos para la biodiversidad que solo minimiza los costos de oportunidad. Posteriormente examinamos los costos de añadir objetivos para los servicios del ecosistema en este plan. Finalmente, exploramos los pros y contras entre los objetivos de biodiversidad y servicios del ecosistema a un costo fijo. Por lo menos 30\% de cada servicio del ecosistema fue capturado incidentalmente cuando se cumplían todos los objetivos de biodiversidad. Al incluir datos sobre los servicios del ecosistema, incrementamos la cantidad de servicios capturados en por lo menos $20 \%$ para los tres servicios sin costos adicionales. Cuando los objetivos de biodiversidad fueron reducidos en $8 \%$, se obtuvo $40 \%$ adicional de provisión de forraje y recarga de agua y se podía capturar $58 \%$ de carbono por el mismo costo. El costo de oportunidad (en términos de producción soslayada) de salvaguardar 100\% de los objetivos de biodiversidad fue de US\$500 millones aproximadamente. Nuestros resultados mostraron que con una pequeña reducción en los objetivos de biodiversidad, se pueden obtener ganancias sustanciales para la conservación de servicios del ecosistema en nuestras áreas prioritarias para la biodiversidad sin costo adicional.

Palabras Clave: almacenamiento de carbono, costos de oportunidad, evaluaciones de biodiversidad, pago de servicios del ecosistema, planificación de la conservación, provisión de forraje, recarga de agua

\section{Introduction}

Ecosystem services are the benefits humans derive from natural systems. Delivery of these services relies on a certain level of biological resource base (natural capital), and the degree to which all species contribute to this is unknown (Myers 1996; Balvanera et al. 2001). Reports on the ongoing degradation and unsustainable use of ecosystem services around the world highlight the urgent need to develop strategies to safeguard them (Balvanera et al. 2001; van Jaarsveld et al. 2005; Chan et al. 2006). Responses to this urgency include the emergence of new initiatives on ecosystem-service planning and management (e.g., Natural Capital Project [http://www.naturalcapitalproject.org] and Valuing the Ark [Fisher \& Turner 2008]). These responses are based on over two decades of research and learning in the field of conservation biology, especially conservation planning (identification of priority areas for conservation action). By broadening their focus from the conservation of biodiversity alone to the conservation of biodiversity and ecosystem services, these initiatives propose to increase the support and resources available for conservation efforts (Armsworth et al. 2007, but see McCauley 2006). Unlike biodiversity, ecosystem services are defined by their link to human values and to particular beneficiaries. Furthermore, payment for ecosystem services schemes can be used to generate money for conservation efforts, and organizations from multiple sectors can work together to improve implementation success. For example, Naidoo and Ricketts (2006) analyzed ecosystem services and biodiversity to demonstrate the costs and benefits of various conservation options within a nature conservation area. The inclusion of ecosystem services and their anthropocentric values in conservation planning should help improve the relevance and ease implementation of conservation programs.

Although the potential benefits from an integrated approach to safeguarding ecosystem services and biodiversity seem logical, the real benefits, trade-offs, and costs of safeguarding both simultaneously are still unclear. Few researchers have investigated the synergies and trade-offs associated with trying to safeguard both ecosystem services and biodiversity (but see Chan et al. 2006; Naidoo et al. 2008; Nelson et al. 2008). Chan et al. (2006) were among the first to investigate explicit planning for ecosystem services and biodiversity. This and other assessments focused on spatial coincidence of ecosystem service and biodiversity priorities, highlighting the low levels of congruence. Chan et al (2006) found that in their study region priorities for ecosystem services did not always coincide spatially with priorities for biodiversity conservation. They evaluated the additional area required to meet ecosystem service targets over and above meeting biodiversity targets.

We sought to move beyond the analysis of spatial congruence of biodiversity and ecosystem services to an assessment of the synergies, trade-offs, and opportunity costs of an integrated approach to safeguarding ecosystem services and biodiversity in the Little Karoo of South Africa. Specifically, we evaluated the amount of ecosystem services captured incidentally by a conservation plan focused on biodiversity only, determined whether one can improve the amount of ecosystem services captured 
by simply including data on service distribution without increasing opportunity costs or reducing biodiversity targets, and explored the consequences of including ecosystem services into a conservation plan for both biodiversity targets and total opportunity costs.

\section{Methods}

\section{Study Area}

The Little Karoo region $\left(19,730 \mathrm{~km}^{2}\right.$ ) (Fig. 1) is a semiarid, intermontane basin, where vegetation associated with three biomes (Succulent Karoo, Fynbos, and Subtropical Thicket biomes) intersects and intermingles (Vlok et al. 2005). All three biomes are recognized as biodiversity hotspots, namely the Succulent Karoo, MaputalandPondoland-Albany (Subtropical Thicket), and Cape Floristic Region (Fynbos) (Mittermeier et al. 2005). Grazing and browsing by domestic livestock (especially ostriches) form the dominant land use and have resulted in extensive overgrazing and degradation of more than $50 \%$ of the region. Another $10 \%$ of the land has been converted to cultivated areas (mostly for livestock feed) (Thompson et al. 2009). Only about $49 \%$ of the vegetation is natural. This degradation has resulted in declines in biodiversity condition (Rouget et al. 2006) and substantial declines in ecosystem services, including water supply, erosion, and flood control (Reyers et al. 2009).

These declines have precipitated a regional stakeholder forum (Gouritz Initiative Forum)-developed under the auspices of CapeNature (a government conservation organization) - to explore interventions to improve the sustainability of the Little Karoo. These interventions include land-management programs, tourism development, and the investigation of carbon markets for restoration (Forsyth et al. 2008). Conservation plans targeting biodiversity features have been developed for the region; however, the pace of implementation has been slow and is hampered by jurisdictional issues (most of the land is managed for livestock production, where practices are regulated by the government department of agriculture and not CapeNature), limited capacity, and lack of appeal to many stakeholders of the planning outcomes (A. T. Lombard et al., unpublished data). The ecosystem services of carbon storage, water supply, and fodder production remain important avenues for speeding up the pace of implementation because these services are likely to have more appeal to stakeholders than conservation of biodiversity per se (Pierce et al. 2005; A.T. Lombard et al., unpublished data).

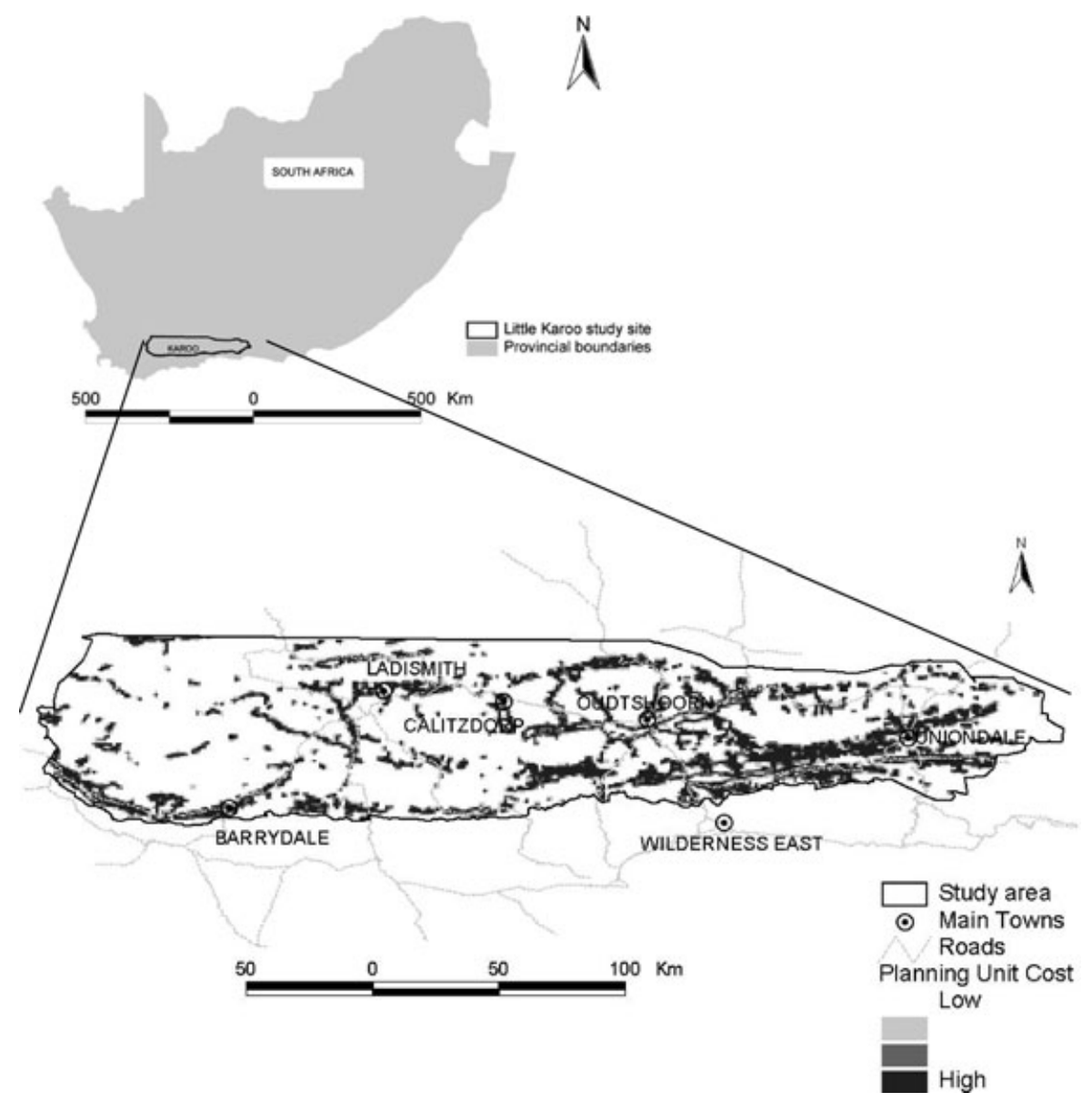

Figure 1. Map of study area in South Africa with variability in planning unit costs in Little Karoo. 


\section{Data Description}

\section{BIODIVERSITY}

We used Little Karoo vegetation data digitized from polygons hand-drawn on Landsat images after extensive field surveys (Vlok et al. 2005). The fine-resolution, hierachical map (1:50,000) contained 56 habitats types and 369 vegetation types. No comprehensive fine-scale coverage of species point-locality data exists for the study area. We used the quantitative species-turnover approach (Desmet \& Cowling 2004) to develop targets for the Little Karoo vegetation types at the level of the habitat type. The targets ranged from conservation of $16-34 \%$ of original extent of each habitat type (Gallo et al. 2009). A land-cover and -degradation map of the study area was used to evaluate the amount of vegetation remaining in a pristine or moderately degraded condition (Thompson et al. 2009). Areas under cultivation and urban or severely degraded areas were classified as transformed and were not considered to contribute to biodiversity targets.

\section{ECOSYSTEM SERVICES}

We considered three ecosystem services: carbon storage, fodder provision by natural vegetation (no supplementary feed required [hereafter, fodder provision]), and water recharge. We estimated the amount of each ecosystem service provided by each vegetation type under intact and degraded (moderate and severe in some cases) conditions as deduced from the land-cover map. Ecosystem services generated in cultivated and urbanized areas were set to zero for carbon storage and fodder provision. The background and detailed descriptions of ecosystem services can be found in Reyers et al. (2009). Below we provide a brief description of how the ecosystem services were mapped. The 369 vegetation types were aggregated into 32 major types relevant to the agriculture and wildlife industry in the region by considering the physiognomy of the vegetation units (Vlok et al. 2005). Where the vegetation map formed the basis for mapping ecosystem services, the 32 habitat types were used.

The retention of carbon stored below or above the ground has the potential to mitigate climate-change impacts. Similar to Chan et al (2006) we considered carbon storage a service because maintaining vegetation in a natural state provides a service to society and a livestockproduction cost to the landowner. Carbon storage for each of the 32 habitats was estimated by experts on the basis of the upper limit provided by data from vegetation adjacent to our study area (arid thicket: $20 \mathrm{t} \mathrm{C} \mathrm{ha}^{-1}$ [Mills \& Cowling 2006]) and data for analogous vegetation from elsewhere in the world (see Mills et al. 2007). Due to lack of information (other than for arid thicket) on age and rates of accumulation, the experts only considered storage potential on the basis of current amounts.
We used these data to estimate carbon storage per planning unit (the building block of a reserve network) (1- $\mathrm{km}^{2}$ grids) for the entire study area. The total amount of carbon stored in the study area was about $8.3 \times 10^{7}$ tons of carbon.

We used a map showing sustainable livestock carrying capacity (hectares per large stock unit [LSU]; prepared by the Department of Agriculture) to estimate fodder provision. We overlaid this carrying-capacity map with the vegetation map to obtain the area per LSU required for sustainable grazing per habitat type under pristine and degraded conditions. Expert knowledge was used to verify the produced carrying capacities and to adjust boundaries that created problems of scale and poor estimations in the carrying-capacity map. We then converted carrying capacity to stocking rates per planning unit. We assumed that if an area was selected for conservation, grazing rates would be reduced to sustainable levels, thus providing fodder for wildlife or livestock. The study area could provide fodder for about 21,585 LSU without degrading the environment. By doubling the sustainable stocking density, pristine vegetation would be degraded within 20 years.

Ground water is the main regulator of water flows in river systems. Data on ground-water quality were extracted from borehole water analysis stored in the Water Management System database of the Department of Water Affairs and Forestry. The results were summarized by the primary lithology taken from the $1: 1$ million geological data (Council for Geosciences 1997). Groundwater recharge was estimated for pristine, moderately degraded, and transformed areas separately (Reyers et al. 2009). The ecosystem service was mapped as millions of cubic meters of groundwater recharge per planning unit. The total amount of ground-water recharge for the study area was $3.8 \times 10^{8}$ million $\mathrm{m}^{3}$.

\section{OPPORTUNITY COST}

We set the cost of conserving a planning unit equal to the net discounted present value of the irrigated crop that produces the highest per annum net returns in the planning unit over the next 50 years or, if irrigation is not feasible in the planning unit, we used the net discounted present value of commercial-level grazing in the planning unit over the next 50 years. Gross margins at the farm gate (income derived from prices on the farm, as derived from census and industry data) were used as value estimates for opportunity costs (in terms of lost production) of conservation. Gross-margin estimates for the deciduous fruit industry and selected cash crops were derived from the literature (Deciduous Fruit Producers Trust 2008; Statistics South Africa 2002) and presented in terms of hectares per planning unit. Because most uncultivated areas with potential for cultivation are adjacent to cultivated areas, we determined potential cultivation areas by buffering 
existing cultivated areas with a 500-m radius. The maximum value of potential or actual revenue generated from cultivation was summarized per planning unit. These values are only estimates because they could change on the basis of several factors that include demand and supply of these products. We assumed landowners act rationally, choosing the land use that will maximize profit (although often only in the short term). We took the net present value (NPV) as an estimate of landowner's willingness to accept land-use change according to a conservation stewardship program (Gallo et al. 2009).

\section{Analysis}

We used simulated annealing within MARXAN (version 1.8.2), which selects sets of reserve systems that meet targets for biodiversity features at a minimal cost (Possingham et al. 2000). All data were summarized at the level of the planning unit $\left(1-\mathrm{km}^{2}\right.$ equal-sized areas, 19,357 in total). MARXAN selects multiple sets of alternative networks, all of which are near optimal at achieving the conservation objective. A species penalty factor determines the importance of meeting targets-higher penalties can be set for not meeting targets for the most important features to increase the likelihood of the target being met, or penalties can be set high for all features if meeting all targets is a requirement.

We designed four scenarios (1, biodiversity only target; 2 , biodiversity and ecosystem services target; 3 , trade-off between biodiversity and ecosystem services targets; 4 , flexible budget) to evaluate the consequences of different conservation strategies for safeguarding biodiversity and ecosystem services in the Little Karoo. A zero cost was assigned to any planning unit classified as protected, and these units were selected in every scenario. At least 100 runs with 1,000,000 iterations were used for each analysis.

The objective with the biodiversity only target was to assess the amount of an ecosystem service captured in areas selected to meet biodiversity targets most efficiently. We did this across a range of biodiversity targets at 5\% intervals, from $10 \%$ to $100 \%$ of the original target specified in Desmet and Cowling (2004). We estimated the opportunity cost of achieving the targets with the best solution from MARXAN at each target level, which is the network that meets the targets at least cost. We also estimated the amount of ecosystem services captured incidentally in the best solution, compared with the amount of ecosystem services captured in a randomly drawn sample (repeated 100 times) equal to the area selected at each target level.

To target biodiversity and ecosystem services, we investigated the influence of including data on ecosystem services in the conservation plans described in scenario 1. Within each target level, the opportunity cost was fixed at the cost of meeting the biodiversity targets in scenario 1 .
For example, at the biodiversity target of $10 \%$, the opportunity cost of meeting $10 \%$ biodiversity targets was held constant and ecosystem-service targets were introduced and gradually increased to find the maximum amount of ecosystem services captured for the same opportunity cost while meeting biodiversity targets. This was carried out for all three ecosystem services.

The objective of trading off biodiversity and ecosystem services targets was to evaluate the trade-offs between the two by finding out how much ecosystem services can be captured by reducing some biodiversity targets within a fixed opportunity cost. A cost threshold was set (cost of meeting $50 \%$ of biodiversity targets), and different ratios of biodiversity to ecosystem-service conservation were explored. We used the 50\% target because at the 100\% target much of the study area is selected leaving little room for the flexibility required in this scenario. Scenario 1 told us how much of each ecosystem service was captured by meeting $50 \%$ of the biodiversity targets. We systematically increased this amount for each ecosystem service and calculated the number of biodiversity features whose targets were not met for the same opportunity cost.

We used the flexible-budget scenario to assess the increased opportunity cost of increasing targets for ecosystem services while maintaining biodiversity targets. We held biodiversity targets constant at $50 \%$ of the original targets (as per scenario 3) and systematically increased targets for each ecosystem service and calculated the cost increase of the resulting conservation-area network. The starting target for each ecosystem service was the amount captured incidentally while planning for biodiversity alone and meeting $50 \%$ of the biodiversity target.

\section{Results}

There was a high degree of cost variability throughout the study site (Fig. 1). The NPV of planning units ranged from US $\$ 0$ to $\$ 8,152,000$. The average NPV per planning unit was $\$ 1,823,000$. The most profitable land use was the cultivation of deciduous fruits. Most of the high-value lands were concentrated in the low-lying eastern parts of the study area.

The NPV of the land that met $100 \%$ of the biodiversity targets was about $\$ 8.3$ billion (opportunity cost of $\$ 500$ million/year). When only $50 \%$ of the biodiversity targets were met, the NPV of the land required dropped to about $\$ 3.2$ billion.

When the full biodiversity targets were met (scenario 1), approximately $37 \%$ of all carbon stored in the study area, $45 \%$ of all fodder, and $57 \%$ water recharge were captured incidentally. Meeting $50 \%$ of the target captured $23 \%$ of carbon, $32 \%$ fodder provision, and $48 \%$ water recharge. We observed a roughly linear increase in both 

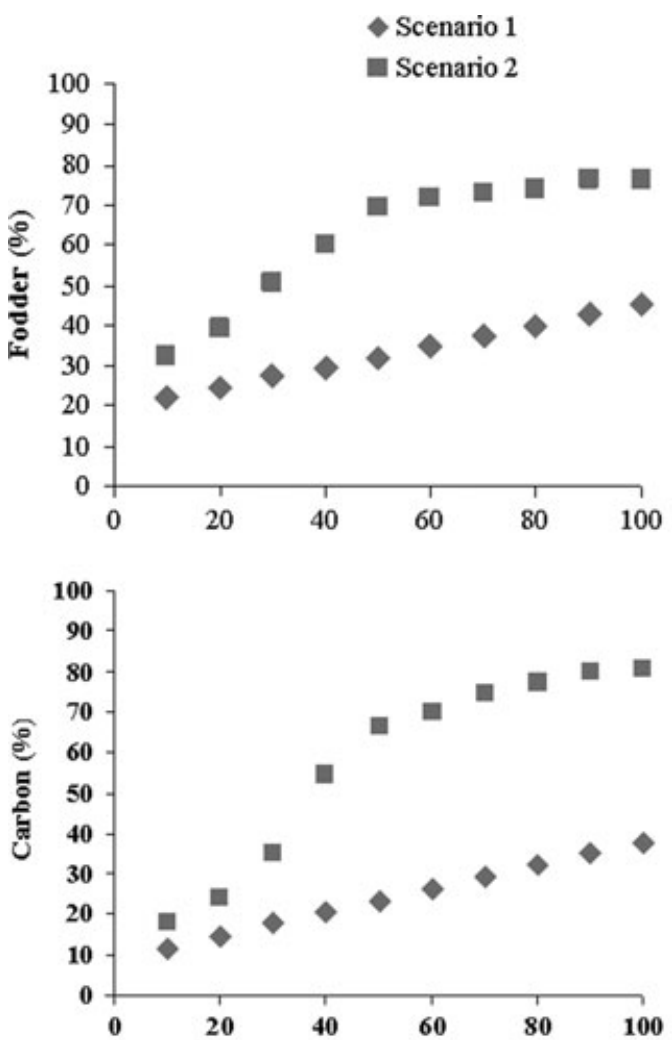

(b)

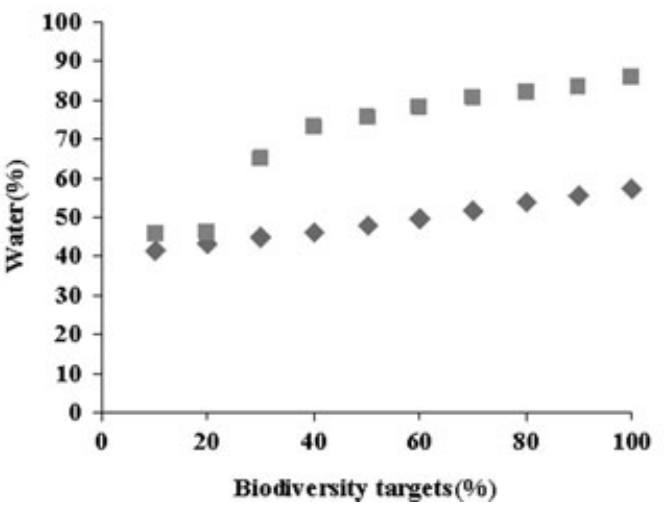

(c)

Figure 2. Percent increase in ecosystem service ([a] fodder; [b] carbon; [c] water) captured by increasing biodiversity targets for two conservation plans, one of which targets ecosystem service (scenarios 1 and 2). Scenario 1 bad data only on biodiversity, whereas scenario 2 bad data on biodiversity and ecosystem services within the same opportunity cost.

the amount of ecosystem services captured incidentally and cost (and the area requiring conservation) as we increased biodiversity targets (Fig. 2a-c). When the outputs of scenario 1 were compared with random selections, the number of LSUs for fodder provision captured was not significantly different, the amount of carbon captured was lower, and water recharge was significantly higher than the random sample.

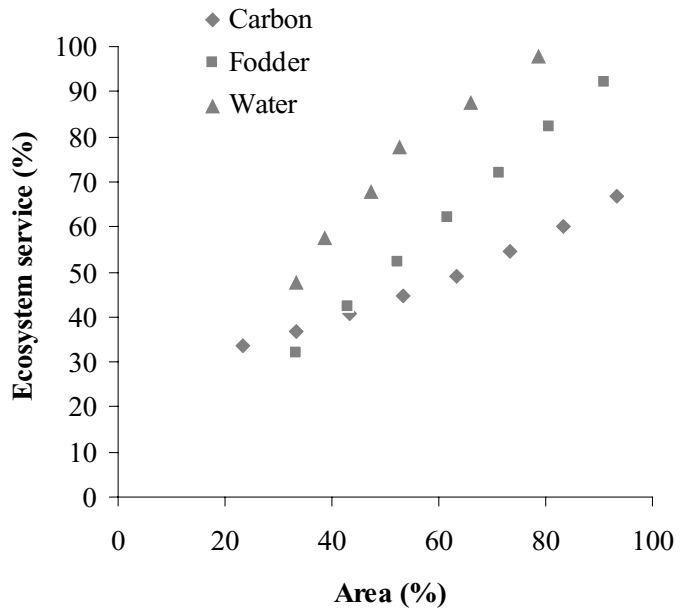

Figure 3. Increase in percentage of area selected as ecosystem-service targets increased (scenario 2).

The amount of ecosystem services captured by targeting ecosystem services within the same opportunity cost threshold as scenario 1 (scenario 2) increased by at least $20 \%$ for water and 30\% for carbon and fodder provision (Fig. 2a-c). In this scenario, MARXAN selected more planning units (Figs. $3 \& 4 \mathrm{a}-\mathrm{d}$ ). The large variation in the cost of planning units allowed MARXAN to trade planning units with higher opportunity cost selected for biodiversity only with cheaper ones that contributed to both biodiversity and ecosystem service objectives. For example, a reserve network aimed at meeting biodiversity targets and $37 \%$ of carbon storage was 1.5 times larger than that for biodiversity only, but had the same total opportunity cost. Although these two conservation-area networks shared about $65 \%$ of the planning units, $9 \%$ of the planning units selected for the biodiversity-only network and not selected for the integrated network had much higher opportunity costs. The difference in the number of planning units selected for the biodiversityonly network and for both biodiversity and ecosystem service network was greatest for carbon compared with the other two services.

Relinquishing small amounts of biodiversity resulted in large gains in ecosystem services in scenario 3 for the same total opportunity cost as scenarios 1 and 2 . When targets for $8 \%$ of the biodiversity features (vegetation types) were not met, an extra $40 \%$ of fodder provision and water recharge and $58 \%$ of carbon were captured for the same total opportunity cost. Nevertheless, more than $70 \%$ of the vegetation types whose target were not met had lost at least $50 \%$ of their original extent and were recognized as threatened ecosystems.

Increasing targets for ecosystem services by about $30 \%$ (scenario 4) did not significantly increase the opportunity cost of the network from the biodiversity-only amount (Fig. 5). Nevertheless, the percentage of area required 
(a)

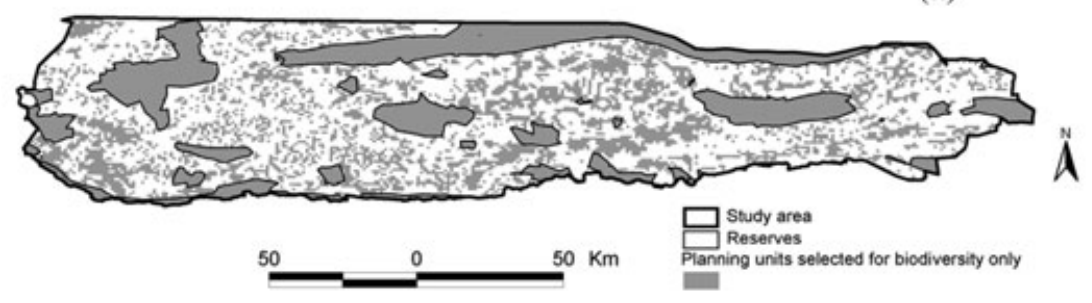

(b)

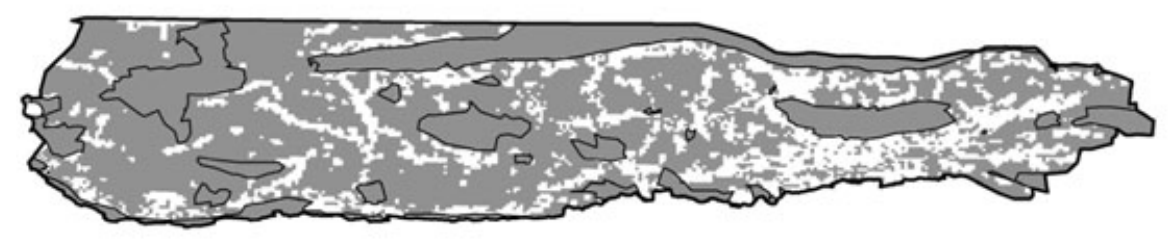

(c)

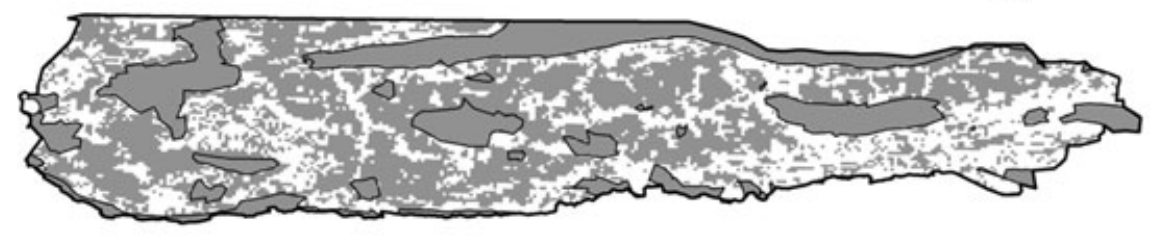

(d)

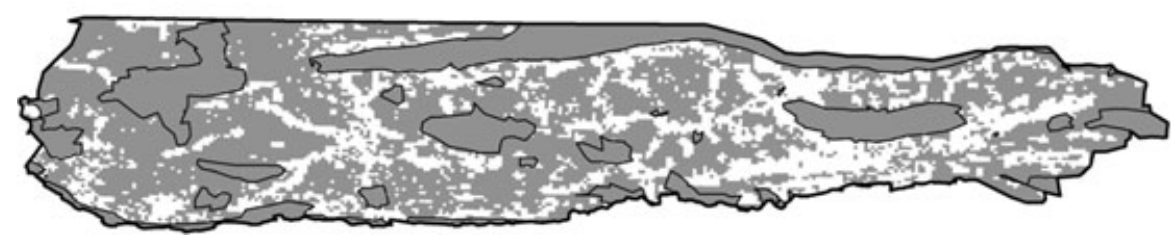

Figure 4. Map of study area showing conservation priorities when only biodiversity is targeted in scenario 1 and when both biodiversity and various ecosystem services are targeted simultaneously in scenario 2: (a) targets biodiversity only; (b) targets biodiversity and fodder; (c) targets biodiversity and carbon; and (d)) targets biodiversity and water recharge. for conservation increased significantly. For example, a $10 \%$ increase in target for fodder provision did not significantly increase the cost but resulted in a $10 \%$ increase in area. Beyond this amount, we could increase targets for carbon for a lower increase in cost than that for the other two services.

\section{Discussion}

\section{Biodiversity-Based Conservation Plans and Ecosystem} Services

Although it is true that conservation plans designed to conserve biodiversity do capture some ecosystem services coincidentally (e.g., Naidoo et al. 2008), our results show that by including data on ecosystem services, conservation plans can be far more efficient in selecting areas for both biodiversity and ecosystem services at no or at minimal additional costs. So although there may be biodiversity features that co-occur with some ecosystem services at global and local scales (Chan et al. 2006; Turner et al. 2007; Egoh et al. 2009) and some congru- ence between different ecosystem services (Chan et al. 2006; Egoh et al. 2008; Reyers et al. 2009), inclusion of data on biodiversity and ecosystem services allows the conservation plan to optimize all targets as efficiently as possible. This will be particularly true in regions where alternative options for meeting biodiversity targets still exist. In the Little Karoo there are still large tracts of pristine or moderately degraded land, which means the conservation plan can select several different combinations of planning units to meet biodiversity targets. If one includes data on ecosystem services in this conservation plan, then this will guide the selection of planning units to those that meet biodiversity and ecosystem-service targets without changing the associated opportunity costs. In parts of the world where land-cover change is more widespread and options are more limited, trade-offs between biodiversity and ecosystem service targets will be stronger where budgets are limited.

In our study these trade-offs began to develop in scenario 3, where, as we increased ecosystem-service targets some biodiversity features could no longer meet their targets within a constrained budget. This indicates 


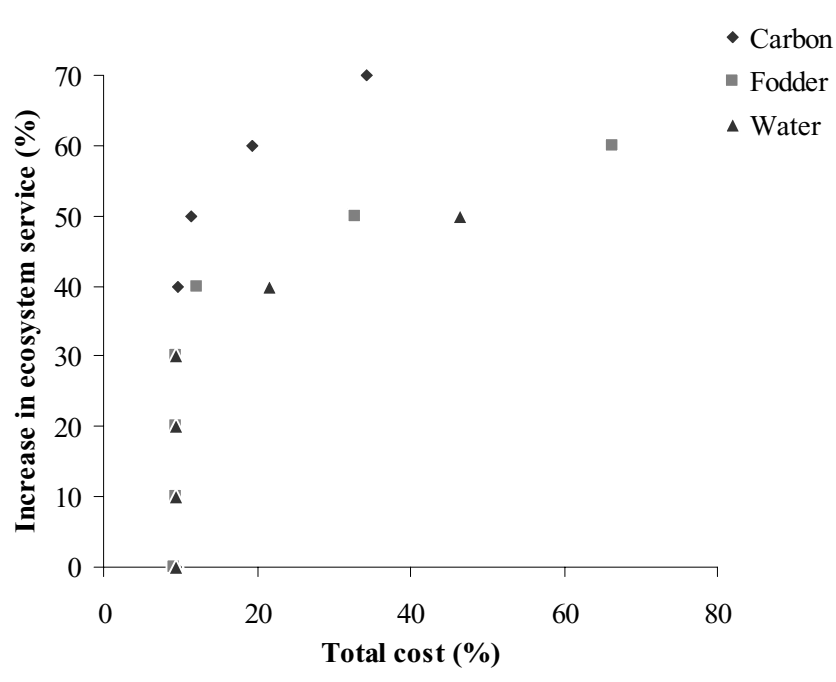

Figure 5. Cost of increasing targets for ecosystem services starting with a biodiversity plan that meets $50 \%$ of the targets for vegetation types at the minimum cost (scenario 4).

there are areas that perform well in meeting biodiversity targets but not ecosystem services and vice versa. The biodiversity features traded for ecosystem services in scenario 3 were mostly those that were already threatened. These vegetation types with limited extant cover need the most conservation action. One way of solving this problem is to assign a higher penalty factor to any such important conservation feature, so that less-vulnerable features will be traded off instead. Including ecosystem services in a biodiversity plan comes at some cost to biodiversity. However if the use of ecosystem services as a marketing tool can increase the pool of funds for conservation, then we could theoretically increase the protection of biodiversity.

\section{Costs of Conservation}

The Little Karoo, like the rest of South Africa, consists of mostly privately owned land with state land totaling $<20 \%$ of the region (Gallo et al. 2009). This implies that the costs of safeguarding biodiversity and ecosystem services in the Little Karoo will include acquisition or opportunity and other compensatory costs. The estimated opportunity costs of $\$ 500$ million for scenario 1 is very high when compared with existing conservation budgets, which currently total \$12 million/year for CapeNature, the agency tasked with managing the entire Western Cape Province's conservation areas (Frazee et al. 2003). Gallo et al. (2009) demonstrated the role privately owned reserves can play in helping to achieve conservation goals in the Little Karoo, especially in the more productive (and expensive) lowland areas. Currently, the reasons land owners conserve their land are not well understood, but they appear to include pro-conservation values, the benefits of tourism, the game industry, and lifestyle choices (O'Farrell et al. 2008).

The data and techniques we used here could prove helpful in identifying synergies between biodiversity targets, land-owner choices, and new incentives provided by ecosystem services. For example, meeting biodiversity targets in the Little Karoo also ensures the storage of about 31 million tons of carbon; at the time of this study, carbon was trading at prices ranging from $\$ 6.46$ to $\$ 38.46 / \mathrm{t} \mathrm{CO}_{2}$ (Katoomba 2008). At a conservative price of $\$ 7.50 / \mathrm{t} \mathrm{CO}$ (about $\$ 27 / \mathrm{t}$ of carbon), the carbon captured in this study could produce an income of about a billion dollars (including transaction costs) for avoided carbon release (also see Mills et al. 2007). Programs of payment for ecosystem services globally, however, are directed toward sequestration rather than storage. In this regard, projects in and adjacent to the study area aimed at earning carbon credits via the restoration of Arid Thicket are already being implemented on publically and privately owned land (Mills et al. 2007; Blignaut et al. 2008). Finally, sustainable grazing has the potential to generate about $\$ 6.5$ million in livestock sales.

While our results appear to support integrated planning for biodiversity and ecosystem services, there are many practical challenges that lie ahead. These include the scale of benefit flows, the absence of markets, and institutional needs. Although there is the potential for landowners to benefit from sustainable use of the land, a shift in land use is only possible if the benefits are made clear. Carbon storage benefits are global, yet landowners can derive local benefits through international markets, although transaction costs are high (Mills et al. 2007). Water provision, on the other hand, generates benefits at a variety of scales, but markets are either absent or weak, and currently there is little incentive for landowners to safeguard water supplies beyond their property. Fodder provision benefits the landowner directly, but in this case they can make greater short-term profits by overstocking land and buying additional feed (O'Farrell et al. 2008). It becomes clear that identifying areas where one can safeguard biodiversity and ecosystem services will need to be supplemented with the creation of new markets, institutions, and certification processes to ensure that these benefits are realized. It will take time and effort to establish these institutions, markets, and processes and to build the necessary capacity to support these schemes (Cowling et al. 2008). Support and resources from government and nongovernmental organizations are vital in these early phases (e.g., Turpie et al. 2008).

\section{Biodiversity and Ecosystem Service Trade-offs}

The trade-offs evident in scenario 3, where increasing ecosystem service targets are traded off against biodiversity targets under a limited budget, highlights a final cautionary note in integrated planning. These trade-offs 
would have been even greater if we had used more limited (and real) budgets. What these trade-offs indicate is that there will be pieces of land or biodiversity features that will rely on agencies and resources dedicated to the intrinsic value of biodiversity.

Bohensky et al. (2004) argue that making trade-offs transparent to decision makers can help clarify the likely consequences of alternative choices. In support of this need for information, tools and methods to quantify the trade-offs between biodiversity and ecosystem services will be essential. MARXAN and the scenarios we used here provide a useful start; however, further development is needed to investigate the relationship between biodiversity and ecosystem service targets across a range of services and contexts. For example, we have used only one biodiversity feature (vegetation types) and three ecosystem services in the study area. These ideas need to be developed further to include more biodiversity features and ecosystem services in data-rich regions and how they can be applied in data-poor regions. Software that can place planning units into management zones of differing costs, actions, and contributions to targets will also be very valuable in recognizing the different management requirements of biodiversity and ecosystem services.

\section{Conclusions}

Here, we provide a way to explore opportunities for the joint protection of biodiversity and ecosystem services and illustrate that both can be achieved without compromising biodiversity conservation. If the revenue discussed here and those from other sustainable land uses are combined, the opportunity cost of conservation becomes smaller and makes the tasks of conservation agencies less onerous. Markets and other funding mechanisms provided by ecosystem services could provide additional incentives to land owners to use their land sustainably (Blignaut \& Aronson 2008). Conservation agencies could also use information on potential benefits from sustainable land use to develop stewardship programs. Nevertheless, the benefits of safeguarding biodiversity and ecosystem services will only be realized with the support of markets and institutions for ecosystem services, many of which do not yet exist. We recommend that while work on the data and techniques required for this type of integrated planning progresses is undertaken, attention should also be paid to institutional requirements to ensure that planning results in actions to safeguard biodiversity and ecosystem services (Cowling et al. 2008). Finally, ecosystem services will not solve all the funding and implementation challenges associated with conserving biodiversity. If national and international obligations to biodiversity conservation are to be fulfilled, the money and people committed to biodiversity must remain.

\section{Acknowledgments}

This work was supported by the International Foundation for Science, Stockholm, Sweden, through a grant to B.E., National Research Foundation (NRF) through the DST/NRF Centre of Excellence for Invasion Biology at the University of Stellenbosch, the South African National Biodiversity Institute, Council for Scientific and Industrial Research, the Nelson Mandela Metropolitan University, Centre for Applied Environmental Decision Analysis, School of Biological Science, University of Queensland, Australia, and The National Science Foundation.

\section{Literature Cited}

Armsworth, P. R., K. M. A. Chan, G. C. Daily, P. R. Ehrlich, C. Kremen, T. H. Ricketts, and M.A. Sanjayan. 2007. Ecosystem-service science and the way forward for conservation. Conservation Biology 21:1383-1384.

Balvanera, P., G. C. Daily, P. R. Ehrlich, T. Ricketts, S. A. Bailey, S. Kark, C. Kremen, and H. Pereira. 2001. Conserving biodiversity and ecosystem services. Science 291:2047.

Blignaut, J., and J. Aronson. 2008. Getting serious about maintaining biodiversity. Conservation Letters 1:12-17.

Bohensky, E., B. Reyers, A. S. van Jaarsveld, and C. Fabricius. 2004. Ecosystem services in the Gariep basin: a component of the Southern African Millennium Ecosystem Assessment (SAfMA) Millennium Ecosystem Assessment. Stellenbosch University, Stellenbsoch City, South Africa.

Chan, K. M. A., M. R. Shaw, D. R. Cameron, E. C. Underwood, and G. C. Daily. 2006. Conservation planning for ecosystem services. Public Library of Science Biology DOI:10.1371/journal.pbio.0040379.

Council for Geosciences. 1997. 1:1 000000 scale geological map of the Republic of South Africa and the Kingdoms of Lesotho and Swaziland. Council for Geoscience, Pretoria, South Africa.

Cowling, R. M., B. Egoh, T. A Knight, P. O'Farrel, B. Reyers, M. Rouget, D. Roux, A. Welz, and A. Wilhelm-Rechman. 2008. An operational model for mainstreaming ecosystem services for implementation. Proceedings of the National Academy of Sciences 105:9483-9488.

Deciduous Fruit Producers Trust. 2008. Annual key deciduous fruit statistics. Compiled by the Deciduous Fruit Producers Trust (DFPT) and Optimal Agricultural Business Systems (OABS) for the South African Apple and Pear Producers' Association; Dried Fruit Technical Services; South African Stone Fruit Producers' Association and the South African Table Grapes Producers' Association, Paarl, South Africa.

Desmet, P. G., and R. M. Cowling. 2004. Using the species-area relationship to set baseline targets for conservation. Ecology and Society 9 : http://www.ecologyandsociety.org/iss2/art11.

Egoh, B., B. Reyers, M. Rouget, M. Bode, and D.M. Richardson. 2009. Spatial congruence between biodiversity and ecosystem services in South Africa. Biological Conservation 142: 553-562.

Egoh, B., B. Reyers, M. Rouget, D.M. Richardson, D.C. Le Maitre, and A.S. van Jaarsveld. 2008. Mapping ecosystem services for planning and management. Agriculture, Ecosystems and Environment 127:135-140.

Fisher, B., and R. K. Turner. 2008. Ecosystem services: classification for valuation. Biological Conservation 141:1167-1169.

Frazee, S., R. M. Cowling, R. L. Pressey, J. K. Turpie, and N. Lindenberg. 2003. Estimating the costs of conserving a biodiversity hotspot: a case study of the Cape Floristic Region, South Africa. Biological Conservation 112:275-290.

Forsyth, G., J. Vlok and B., Reyers. 2008. Retention and restoration of the biodiversity of the little Karoo. Report 0118/C. Council of 
Scientific and Industrial Research, Pretoria, South Africa. Available from www.gouritz.com (accessed October 2009).

Gallo, J. A., L. Pasquini, B. Reyers, and R. M. Cowling. 2009. The role of private conservation areas in biodiversity representation and target achievement within the Little Karoo region, South Africa. Biological Conservation 142:446-454.

Katoomba. 2008. Katoomba's group ecosystem marketplace. Forest Trends, Washington, D.C. Available from http:// ecosystemmarketplace.com (accessed June 2008).

McCauley D. 2006. Selling out on nature. Nature 443:27-28.

Mills, A. J., and R. M. Cowling. 2006. Rate of carbon sequestration at two thicket restoration sites in the Eastern Cape, South Africa. Restoration Ecology 14:38-49.

Mills, A. J., J. Turpie, C. Marais, R. M. Cowling, G. I. H. Kerley, R. G. Lechmere-Oertel, A. M., Sigwela, and M. Powell. 2007. Accessing costs, benefits and feasibility in restoring natural capital in subtropical thicket in South Africa. Pages 179-187 in J. Aronson, S.J. Milton, and J.N. Blignaut, editors. Restoring natural capital: science, business and practice. Island Press, Washington, D.C.

Mittermeier, R. A., P. Robles Gil, M. Hoffmann, J. Pilgrim, T. Brooks, C. G. Mittermeier, J. Lamoreux, and G. A. B. da Fonseca. 2005. Hotspots revisited: Earth's biologically richest and most endangered terrestrial ecoregions. Cemex, Mexico City, D.F.

Myers, N. 1996. Environmental services of biodiversity. Proceedings of the National Academy of Sciences 93:2764-2769.

Naidoo, R., and T. H. Ricketts. 2006. Mapping the economic costs and benefits of conservation. Public Library of Science Biology 4 DOI:10.1371/journal.pbio.0040360.

Naidoo, R., A. Balmford, R. Costanza, B. Fisher, R. E. Green, B. Lehner, T. R. Malcolm, and T. H. Ricketts. 2008. Global mapping of ecosystem services and conservation prioritie. Proceedings of the National Academy of Sciences 105:9495-9500.

Nelson, E., S. Polasky, D. Lewis, A. Plantinga, E. Lonsdorf, D. White, D. Bael, and J. Lawler. 2008. Efficiency of incentives to jointly increase carbon sequestration and species conservation on a landscape. Proceedings of the National Academy of Sciences 105:94719476.

O'Farrell, P. J., D. C. le Maitre, C. Gelderblom, D. Bonora, T. Hoffman, and B. Reyers. 2008. Applying a resilience framework in the pursuit of sustainable land-use development in the Little Karoo, South Africa. Pages 383-430 in M. E. Burns and A. v.B. Weaver, editors.
Exploring sustainability science-a Southern African perspective. SUN PReSS, Stellenbosch, South Africa.

Pierce, S. M, R. M. Cowling, A. T. Knight, A. T. Lombard, M. Rouget, and T. Wolf. 2005. Systematic conservation planning products for landuse planning: interpretation for implementation. Biological Conservation 125: 441-458.

Possingham H. P., I. Ball, S. Andelman. 2000. Mathematical methods for identifying representative reserve networks, in quantitative methods for conservation biology. Pages 291-305 in S. Ferson and M. Burgman, editors. Springer-Verlag, New York.

Reyers, B., P. O'Farrell, R. M. Cowling, B. N. Egoh, D. Le Maitre, J. H. Vlok. 2009. Ecosystem services, land cover change, and stakeholders: finding a sustainable foothold for a semiarid biodiversity hotspot. Ecology and Society 14: http://www. ecologyandsociety.org/vol14/iss1/art38/.

Rouget, M., R. M. Cowling, J. H. J. Vlok, M. Thompson, and A. Balmford. 2006. Getting the biodiversity intactness index right: the importance of habitat degradation data. Global Change Biology 12:2032-2036.

Statistics South Africa. 2002. Gross domestic product-fourth quarter 2001. StatsSA, Pretoria.

Thompson M, J. Vlok, M. Rouget, M. T. Hoffman, A. Balmford, and R. M. Cowling. 2009. Mapping land transformation in a heterogeneous environment: a rapid and cost effective approach for assessment and monitoring. Journal of Environmental Management 43:585-596.

Turner, W. R., K. Brandon, T. M. Brooks, R. Costanza, G. A. B Fonseca, R. Portela. 2007. Global conservation of biodiversity and ecosystem services. BioScience 57:868-873.

Turpie, J. K., C. Marais, and J. N Blignaut. 2008. The Working for Water Programme: evolution of a payments for ecosystem services mechanism that addresses both poverty and ecosystem service delivery in South Africa. Ecological Economics 65:788-798.

van Jaarsveld, A. S., R. Biggs, R. J. Scholes, E. Bohensky, B. Reyers, T. Lynam, C. Musvoto, and C. Fabricius. 2005. Measuring conditions and trends in ecosystem services at multiple scales: the Southern African Millennium Ecosystem Assessment (SAfMA) experience. Philosophical Transactions: Biological Sciences 360:425-441.

Vlok, J. H. J., R. M. Cowling, T. Wolf. 2005. A vegetation map for the Little Karoo. Maps and report for a SKEP project supported by grant 1064410304. Critical Ecosystem Partnership Fund, Cape Town. Available from http://bgis.sanbi.org/littlekaroo/index.asp (accessed January 2009).

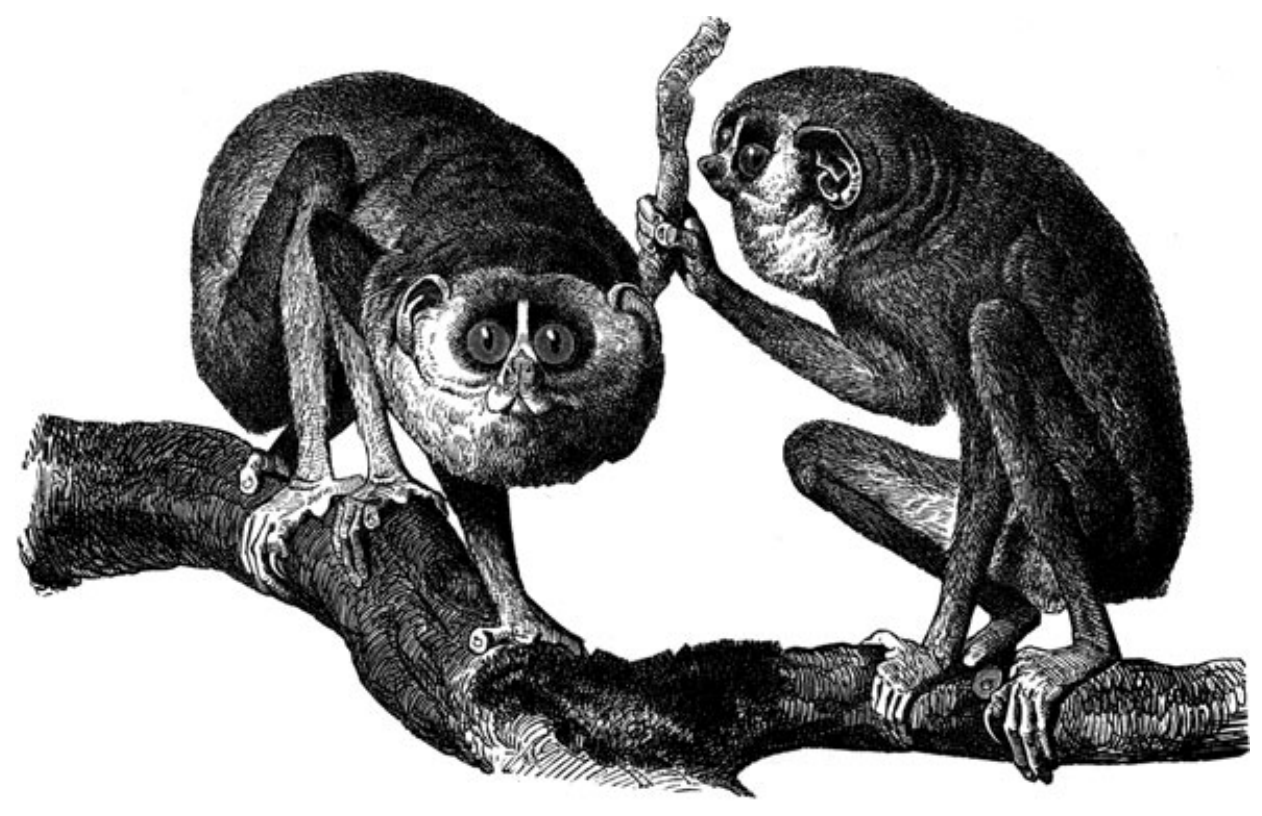

